\title{
Fertility in 47,XXX and 45,X patients
}

\author{
Sir JOHN DEWHURST
}

From the Institute of Obstetrics and Gynaecology, Queen Charlotte's Hospital, Goldhawk Road, London

SUMMARY Female patients with a sex chromosome abnormality may be fertile. In patients with a $\vec{\odot}$ 47,XXX cell line there appears to be an increased risk of a cytogenetically abnormal child but the $\overrightarrow{\vec{H}}$ extent of this risk cannot yet be determined; it is probably lower in the non-mosaic 47,XXX patient ${ }_{\sigma}^{\omega}$ than the mosaic $46, X X / 47, X X X$ one. Patients with a $45, X$ cell line rarely become pregnant, and when they do they appear to have a high risk of an abnormal child or repeated unsuccessful pregnancies; this? risk is certainly exaggerated by the method of reporting; when the poor reproductive performance is $\overrightarrow{0}$ first identified leading to the recognition of the maternal cytogenetic fault, the reproductive failure rate $e_{-}^{\sim}$ is naturally high; when the maternal fault is first identified and the reproductive history then established $\mathrm{N}^{\omega}$ far better results are evident.

Patients with sex chromosome anomalies usually present in clinical practice as examples of gonadal dysgenesis with primary amenorrhoea, streak gonads, and absolute sterility. There are exceptions, however, notably individuals with a 47,XXX karyotype who are known to be fertile (Barr et al., 1969) and certain patients with a mosaic karyotype or with deletions or isochromosomes who develop a degree of ovarian differentiation compatible with secondary sexual development, menstruation, or rare fertility (Dewhurst and Lucas, 1971). The reproductive performance of the $47, \mathrm{XXX}$ group is surprisingly good though a small number of children who are cytogenetically abnormal have been described. The reproductive performance in the latter group is alarming, the outcome being an abortion or an abnormal child in a high percentage of reported cases. A thorough review of the subject seemed appropriate in an attempt to clarify the picture and to determine with greater certainty the risk of an abnormal child or an unsuccessful pregnancy in such patients.

\section{$47, X X X$ and $46, X X / 47, X X X$ patients}

Barr et al. (1969), in a comprehensive review of patients with the above karyotypes, reported on 28 women who had had 67 children, 2 abortions, and 2 terminations of pregnancy. Twenty-nine children had been examined cytogenetically and 24 were found to be normal. The 5 women who bore abnormal children were one with a $47, \mathrm{XXX}$ karyotype, and 4 with a 46,XX/47,XXX karyotype (Table 1) (Rosenkranz, 1965a,b; Fujita and Yamamoto, 1967; Williams, 1969). It is interesting that there were 4 cytoReceived for publication 31 August 1977 genetically abnormal children among the 14 offspring from only 8 patients with a mosaic karyotype and only $\vec{\varphi}$ one cytogenetically abnormal child from the remaining patients whose karyotype was $47, \mathrm{XXX}$. Since the report of Barr et al., Kadotani et al. (1970) have reported one 47,XXX patient who gave birth to a childs with trisomy 21 Down's syndrome; 4 other abnormalō children have, however, been reported who were borno to mosaic 46,XX/47,XXX patients (Table 2) (Baikies et al., 1972; Geisler et al., 1972; Tsuang et al., 1975; Zizka et al., 1975).

These data indicate a greater liability to abnormas offspring in mosaic than non-mosaic patients buto. suggest that patients with either may have an increased risk of bearing an abnormal child. From theo information at present available it is not possible too determine how great this risk might be. $47, \mathrm{XXX}$ of mosaic $46, \mathrm{XX} / 47, \mathrm{XXX}$ women show no charac? teristic clinical features and many who bear a normak child will undoubtedly escape recognition unless 2 deliberate search is made for them (Lucas et al., $>$ 1971), while those who bear an abnormal child are byㅡㅡㄹ contrast more likely to be recognised and reported Indeed a careful scrutiny of the cases referred to above in which abnormal children were born to mothers with a 47,XXX cell line shows that in every case the discovery of the abnormality in the child led to theo recognition of the abnormal karyotype in the mother thus exaggerating the apparent risk. All that can be concluded at present, therefore, is that a mosaicen $46, X X / 47, X X X$ mother may possess an increased risk of fetal anomaly; we do not know how great this risk iso but it is probably greater than that run by a $47, \mathrm{XXX}$ non-mosaic mother. We cannot conclude as wasD 
Table $147, X X X$ and 47, $X X / 47, X X X$ patients (Barr et al., 1969)

\begin{tabular}{|c|c|c|}
\hline Authors & Mother & Child \\
\hline Rosenkranz (1965a,b) & $\begin{array}{ll}1 & 47, X X X \\
2 & 46, X X / 47, X X X \\
3 & 46, X X / 47, X X X\end{array}$ & $\begin{array}{l}\text { Klinefelter's syndrome } \\
46, X X / 47, X X X \\
\text { Klinefelter's syndrome; } \\
\text { Normal son }\end{array}$ \\
\hline Fujita and Yamamoto (1967) & $446, X X / 47, X X X$ & $\begin{array}{l}\text { Klinefelter's syndrome; } \\
\text { Normal son; } \\
3 \text { normal daughters }\end{array}$ \\
\hline Williams (1969) & $546, X X / 47, X X X$ & $\begin{array}{l}\text { Klinefelter mosaic } \\
(46, X Y / 47, X X Y)\end{array}$ \\
\hline
\end{tabular}

Table $246, X X / 47, X X X$ patients

\begin{tabular}{|c|c|c|}
\hline Authors & Mother & Child \\
\hline Baikie et al. (1972) & $46, \mathrm{XX} / 47, \mathrm{XXX}$ & $\begin{array}{l}\text { Klinefelter's syndrome; } \\
\mathbf{3} \text { other children }\end{array}$ \\
\hline Geisler et al. (1972) & $46, X X / 47, X X X$ & $\begin{array}{l}\text { Klinefelter's syndrome; } \\
2 \text { normal boys }\end{array}$ \\
\hline Tsuang et al. (1975) & $46, X X / 47, X X X$ & $\begin{array}{l}\text { Klinefelter's syndrome; } \\
\text { Normal boy and girl }\end{array}$ \\
\hline Zizka et al. (1975) & $46, X X / 47, X X X$ & $48, X X Y Y$ \\
\hline
\end{tabular}

recently done by Gerald (1976) that as many as onesixth of the offspring of mothers with a $47, \mathrm{XXX}$ cell line will be abnormal cytogenetically. Amniocentesis and chromosome analysis in early pregnancy appear to be indicated in those rare occasions when a known $47, \mathrm{XXX}$ or mosaic patient becomes pregnant.

\section{Patients with a 45, $X$ cell line}

A review of the literature reveals reports of pregnancies in 5 patients with a 45,X karyotype (Bahner et al., 1960; Nakashima and Robinson, 1971; Grace et al., 1973; Groll and Cooper, 1976; Philip and Sele, 1976), 7 who were 45,X/46,XX (Kava and Klinger, 1968; Bomers-Marres, 1966; Predescu et al., 1969; Bishun et al., 1969; Mackay et al., 1971; Siegelman, 1972; Lieber and Berger, 1973), 4 who were 45,X/ 46,XX/47,XXX (Briggs et al., 1963; de Toni et al., 1965; Armendares et al., 1967; Nielsen and Thomsen, 1968; Giraud, 1970; Hsu et al., 1972; Kim et al., 1975). The outcome of the pregnancy in these patients is set out in Tables 3, 4, 5, and 6 from which it may be seen that 54 pregnancies have occurred resulting in 16 miscarriages, 1 termination, 12 abnormal children, 3 children who were stillborn without sufficient details to

Table $345 X$ patients

\begin{tabular}{ll}
\hline Authors & Offspring \\
\hline Bahner et al. (1960) & Male: chromatin negative \\
Nakashima and Robinson (1971) & Female: 46,XX \\
Grace et al. (1973) & Female: 46,XX \\
Groll and Cooper (1976) & Female: stillborn, cord \\
& Female: normal \\
Philip and Sele (1976) & Macerated hydrocephalic \\
& 26 weeks \\
& Male: 46,XY \\
\hline
\end{tabular}

Table 4 45, X/46, XX patients

\begin{tabular}{|c|c|}
\hline Authors & Offspring \\
\hline Kava and Klinger (1968) & $\begin{array}{l}\text { Male: normal } \\
\text { Miscarriage }\end{array}$ \\
\hline Predescu et al. (1969) & $\begin{array}{l}4 \text { miscarriages } \\
\text { Abnormal child? Down's }\end{array}$ \\
\hline Mackay et al. (1971) & $\begin{array}{l}\text { Normal female } \\
\text { growth retarded in utero }\end{array}$ \\
\hline Bomers-Marres (1966) & $\begin{array}{l}\text { Female: normal } \\
\text { Male: normal }\end{array}$ \\
\hline Bishun et al. (1969) & $\begin{array}{l}\text { Male: gross malformations } \\
\text { Male: spina bifida; } \\
\text { Spina bifida and hydrocephalus }\end{array}$ \\
\hline $\begin{array}{l}\text { Lieber and Berger (1973) } \\
\text { Siegelman (1972) }\end{array}$ & $\begin{array}{l}\text { Termination } \\
3 \text { miscarriages; } \\
\text { Male } 45, \mathrm{XY} \\
\text { Famel } 45, \mathrm{X} / 46, \mathrm{XX}\end{array}$ \\
\hline
\end{tabular}

Table $545, X / 47, X X X$ patients

\begin{tabular}{ll}
\hline Authors & Offspring \\
\hline Lewis et al. (1963) & 3 males: normal \\
Maclean et al. (1968) & (a) 1 child: no details \\
Reyes et al. (1976) & (b) 1 child: no details \\
\hline
\end{tabular}

decide the reason, and 22 who were born alive and are now either well or have died for other reasons. Abnormalities encountered in the 12 abnormal children are set out in Table 7.

This is an appalling reproductive performance and gives rise to considerable concern. However, if the reports are divided into those in which the abnormal child or the poor reproductive performance led to the recognition of the maternal faults and those in which the mother's abnormality was discovered first and her fertility record then established, a different picture emerges (Table 8). It is clear that when the mother is identified first her reproductive performance is far better than the impression given by the review of the patients as a whole. Indeed, as with the group of $47, \mathrm{XXX}$ women, the apparent risk of abnormality is considerably exaggerated by the method of reporting.

Table $645, X / 45, X X / 47, X X X$ patients

\begin{tabular}{|c|c|}
\hline Authors & Offspring \\
\hline de Toni et al. (1965) & $\begin{array}{l}\text { Female: } 45, X / 46, X X \\
\text { Twins: } 45, X \\
445, X / 46, X X / 47, X X X\end{array}$ \\
\hline Giraud (1970) & $\begin{array}{l}\text { Macerated child } 7 / 12 \text {; } \\
45, X / 46, X Y \text { with congenital heart disease } \\
46, X X \text { : congenital heart disease }\end{array}$ \\
\hline $\begin{array}{l}\text { Briggs et al. (1963) } \\
\text { Nielsen and Thomsen (1968) } \\
\text { Armendares et al. (1967) }\end{array}$ & $\begin{array}{l}\text { Normal female } \\
\text { Male: died } 3 / 12 \text { age } \\
\text { Down's syndrome, trisomy } 21 \\
\text { Male: } 46, X Y\end{array}$ \\
\hline Kim et al. (1975) & $\begin{array}{l}\text { Stillbirth: no details } \\
2 \text { miscarriages }\end{array}$ \\
\hline Hsu et al. (1972) & $\begin{array}{l}\text { (a) } 2 \text { miscarriages } \\
\text { (b) } 3 \text { miscarriages } \\
\text { Male: died leukaemia } \\
\text { Male: Down's syndrome } \\
\text { Male: normal }\end{array}$ \\
\hline
\end{tabular}


Table 7 Nature of abnormality

\begin{tabular}{ll}
\hline Spina bifida & 2 \\
Down's syndrome & 2 \\
? Down's syndrome & 1 \\
Gross malformations & 1 \\
Congenital heart defect & $2^{*}$ \\
$45, X / 46, X X$ & 2 \\
$45, X$ & 1 \\
$45, X / 46, X X / 47, X X X$ & 1 \\
\hline Total & 12 \\
\hline I also $45, X / 46, X Y$ &
\end{tabular}

Table 8 Outcome of pregnancy related to manner of discovery of abnormal maternal karyotype

\begin{tabular}{lcl}
\hline & $\begin{array}{l}\text { From abnormal child } \\
\text { or repeated } \\
\text { miscarriages }\end{array}$ & $\begin{array}{l}\text { Secondary } \\
\text { amenorrhoea or } \\
\text { mental hospital } \\
\text { survey, etc. }\end{array}$ \\
\hline Miscarriages & 14 & $2^{*}$ \\
Termination & 0 & 1 \\
Abnormal children & 12 & 0 \\
$\begin{array}{l}\text { Other stillborn } \\
\text { Alive ?well } \\
\text { or died other reasons }\end{array}$ & 2 & 1 \\
\hline Total & 5 & 17 \\
\hline
\end{tabular}

*One a macerated hydrocephalic.

None the less in the present state of our knowledge pregnant patients with a $45, \mathrm{X}$ cell line must constitute a high risk group in which amniocentesis to detect fetal abnormality might be undertaken. It must be pointed out, however, that this technique may not detect all the abnormalities reported in Table 7, though the majority would be recognised.

\section{Discussion}

This review suggests that the chances of a normal child in those patients with an abnormal sex chromosome complement who are capable of reproduction is greater than it appears to be at first sight. More data are clearly required, however, before any realistic assessment of the risk of abortion or of fetal anomaly can emerge.

One paper has not been included in the review and its omission requires comment. Arakaki and Waxman (1970) successfully cultured endometrium from 68 women who had a spontaneous abortion; 59 endometria were cytogenetically normal, 9 abnormal. They compared the cytogenetic findings in the abortus in the normal and abnormal endometrial groups and found the abnormal endometrial group to have a higher rate of cytogenetically abnormal abortus though there were abnormalities in each. They did not establish the karyotype of the mother by examining the peripheral blood or other tissue and we cannot say whether the chromosome complement obtained from the endometrium was characteristic of the patient's karyotype or not. The paper was not included here, therefore, though further work in this field would clearly be interesting.

Brief mention will be made of the manner in which $a \stackrel{\infty}{\oplus}$ woman with a $45, X$ cell line might retain her repro- $\Rightarrow$ ductive capacity. It is known that the primitive gonads? of 45,X women contain germ cells (Singh and Carro 1966); these are destroyed almost totally by the time of birth or soon afterwards, probably because of the $\frac{\bar{s}}{\bar{\rho}}$ failure of pre-granulosa cells to surround the germ cello and form primary follicles; germ cells not surroundedo in this fashion, but left exposed to ovarian stroma, arequickly destroyed (Baker, 1963). This destruction is to. some extent a normal process during intrauterine $\vec{\omega}$ development and results in a reduction in the numbero of oocytes from almost 7000000 at the fifth month to around 2000000 at birth. In the $45, X / 46, X X$ patient,, especially one with a high proportion of $46, \mathrm{XX}$ cells, $\overrightarrow{\mathrm{r}}$ survival until adult life of sufficient germ cells to? permit fertility is clearly a possibility. Even in patientsc without a large preponderance of $46, \mathrm{XX}$ cells a favour ${ }^{\circ} \mathrm{O}$ able distribution of these cells during early embryonic ${ }^{\text {? }}$ development might have the same effect. In a $45, \mathrm{X}_{\vec{D}}^{-}$ patient we may consider that very rarely germ cello survival could occur permitting fertility in exceptional circumstances. The alternative explanation is that the $\overrightarrow{0}$ fertile 45,X patients reported are in reality unrecog-o nised mosaics. This seems likely in several cases since only one tissue has been examined cytogenetically; moreover in the case reported by Groll and Cooper (1976) for example, the patient's height $\left(5^{\prime} 1 \frac{1}{2}^{\prime \prime}\right){ }_{0}^{\otimes}$ strongly suggests the possibility of a normal cell line区 since it is extremely uncommon for a $45, X$ patient to be so tall. In other patients, however, such as that reported by Philip and Sele (1976), mosaicism is far $\frac{}{\sigma}$ less likely since four tissues were cultured.

\section{References}

Arakaki, D. T., and Waxman, S. H. (1970). Cytogenetics of spon-으 taneous abortion. American Journal of Obstetrics and Gynecology, 107, 1199-1204.

Armendares, S., Buentello, L., Sanchez, J., and Ortiz, M. (1967). 을 $\mathrm{XO} / \mathrm{XX} / \mathrm{XXX}$ mosaicism without Turner stigmata. Lancet, 2 820.

Bahner, F., Schwarz, G., Harnden, D. G., Jacobs, P. A., Heinz, H. A., and Walter, K. (1960). A fertile female with XO sex chromo-O some constitution. Lancet, 2, 100-101.

Baikie, A. G., Dartnall, J. A., and Lickiss, J. N. (1972). XXY son of a possibly XX/XXX mother. Lancet, 1, 697.

Baker, T. G. (1963). A quantitative and cytological study of germo cells in human ovaries. Proceedings of the Royal Society. Series $B, 158,417-433$.

Barr, M. L., Sergovich, F. R., Carr, D. M., and Shaver, E. L. (1969). The triplo-X female: an appraisal based on a study of 12 cases? and a review of the literature. Canadian Medical Association $\square$ Journal, 101. 247-258.

Bishun, N. P., Rashad, M. N., Morton, W. R. M., Mannion, P. L., $\frac{\mathrm{O}}{\mathbb{D}}$ Neely, M. R., and Burke, G. (1969). Chromosomal mosaicism in a case of repeated abortion. Lancet, 1, 936. 
Bomers-Marres, A. J. M. L. (1966). A fertile woman with an $\mathrm{XO}(45) / \mathrm{XX}(46)$ mosaic. Nederlandsch tijdschrift voor Geneeskunde, 110, 1177-1181.

Briggs, D. K., Stimson, C. W., and Vinograd, J. (1963). Leukocyte anomaly, mental retardation, and dwarfism in a family with abnormal chromosomes. Journal of Pediatrics, 63, $21-28$.

de Toni, E., Massimo, L., Vianello, M. J., and Podesta, F. (1965). La casistica di un anno di attivita del Centro di Studi cromosomici della clinica Pediatrica di Genova nel campo delle malformazioni sessuali. Minerva Pediatrica, 17, 578-583.

Dewhurst, C. J., and Lucas, M. (1971). Gonadal dysgenesis and chromosome mosaicism. British Journal of Hospital Medicine, 6, 807-812.

Fujita, H., and Yamamoto, K. (1967). Clinical and cytogenetic studies on one case of XXY and his mother with XX/XXX, and one case of XXX. Acta Paediatrica Japonica, 9, 14.

Geisler, M., Svejcar, J., and Degenhardt, K. (1972). XXY son of an XX/XXX mother. Lancet, 1,955 .

Gerald, P. S. (1976). Current concepts in genetics: sex chromosome disorders. New England Journal of Medicine, 294, 706-710.

Giraud, F. (1970). La fertile des femmes $45, X / 46, X X$ et $45, X /$ 46,XX/47,XXX. Annales de Génétique, 115, 255-258.

Grace, H. J., Quinlan, D. K., and Edge, W. E. B. (1973). 45,X lymphocyte karyotype in a fertile woman. American Journal of Obstetrics and Gynecology, 115, 279-282.

Groll, M., and Cooper, M. (1976). Menstrual function in Turner's syndrome. Obstetrics and Gynecology, 47, 225-226.

Hsu, L. Y. F., Palo-Garcia, F., Grossman, D., Kutinsky, E., and Hirschorn, K. (1972). Fetal wastage and maternal mosaicism. Obstetrics and Gynecology, 40,98-102.

Kadotani, T., Ohama, K., and Makino, S. (1970). A case of 21trisomic Down's syndrome from the triplo-X mother. Proceedings of the Japanese Academy, 46, 709-712.

Kava, H. W., and Klinger, H. P. (1968). Secondary infertility in a phenotypically normal $45, \mathrm{X} / 46, \mathrm{XX}$ female. Fertility and Sterility, 19, 835-838.

Kim, J. H., Hsu, L. Y. F., Paciuk, S., Cristian, S., Quintana, A., and . Hirschorn, K. (1975). Cytogenetics of fetal wastage. New England Journal of Medicine, 293, 844-847.

Lewis, F. J. W., Poulding, R. H., and Eastham, R. D. (1963). Acute leukaemia in an XO/XXX mosaic. Lancet, 2, 306.

Lieber, E., and Berger, J. (1973). Fertility in a $45, X / 46, X X$ patient. Lancet, 1, 199.

Lucas, M., Dewhurst, C. J., Hurley, R., Anderson, S., and Blunt, S. (1971). A search for triple $X$ females in a fertile population. Journal of Obstetrics and Gynaecology of the British Commonwealth, 78, 1087-1092.
Mackay, E. V., Adam, G. S., and Khoo, S. K. (1971). A successful pregnancy associated with sex chromosomal mosaicism of the $\mathrm{XO} / \mathrm{XX}$ type. Australian and New Zealand Journal of Obstetrics and Gynaecology, 11, 259-261.

Maclean, N., Court-Brown, W. M., Jacobs, P. A., Mantle, D. J., and Strong, J. A. (1968). A survey of sex chromatin abnormalities in mental hospitals. Journal of Medical Genetics, 5, 165-172.

Nakashima, I., and Robinson, A. (1971). Fertility in a 45X female. Pediatrics, 47, 770-772.

Nielsen, J., and Thomsen, N. (1968). A psychiatric-cytogenetic study of a female patient with 45/46/47 chromosomes and sex chromosomes XO/XX/XXX. Acta Psychiatrica et Neurologica Scandinavica, 44, 141-155.

Philip, J., and Sele, V. (1976). 45XO Turner's syndrome without evidence of mosaicism in a patient with two pregnancies. Acta Obstetrica et Gynecologica Scandinavica, 55, 283-286.

Predescu, V., Christodorescu, D., Tautu, C., Ciovirnache, M., and Constantinescu, E. (1969). Repeated abortions in a woman with $\mathrm{XO} / \mathrm{XXX}$ mosaicism. Lancet, $2,217$.

Reyes, F. I., Koh, K. S., and Faiman, C. (1976). Fertility in women with gonadal dysgenesis. American Journal of Obstetrics and Gynecology, 6, 669-670.

Rosenkranz, W. (1965a). Klinefelter-Syndrom bei Kindern von Frauen mith Geschlechtschromosomen-Anomalien. Helvetica Paediatrica Acta, 20, 359-368.

Rosenkranz, W. (1965b). Familial mosaicism attributable to a new gene. Lancet, 1, 963-964.

Siegelman, M. (1972). XO/XX and XO/XY mosaicism: a study of a family. Obstetrics and Gynecology, 39, 511-514.

Singh, R. P., and Carr, D. H. (1966). The anatomy and histology of XO human embryos and fetuses. Anatomical Record, 155, 369384.

Tsuang, M. T., Miller, J. R., and De Bault, L. E. (1975). Klinefelter's syndrome and maternal XX/XXX mosaicism. Journal of Medical Genetics, 12, 114.

Williams, L. M. (1969). Cytogenetic study of a $46, \mathrm{XX} / 47, \mathrm{XXX}$ mother and her $46, X Y / 47, X X Y$ son. Proceedings of the Anatomical Society of Australia and New Zealand. Journal of Anatomy, 104, 399.

Zizka, J., Balieek, P., and Nielsen, J. (1975). XXYY son of a triple$\mathrm{X}$ mother. Humangenetic, 26, 159-160.

Requests for reprints to Professor Sir John Dewhurst, Institute of Obstetrics and Gynaecology, Queen Charlotte's Maternity Hospital, Goldhawk Road, London W6 0XG. 